\title{
Evaluation of Therapy Management and Patient Compliance in Postmenopausal Patients with Hormone Receptor-positive Breast Cancer Receiving Letrozole Treatment: The EvaluateTM Study
}

\author{
Evaluation des Therapiemanagements und der Therapieadhärenz bei postmenopausalen Patientinnen \\ mit hormonrezeptorpositivem Mammakarzinom, die mit Letrozol behandelt werden - die EvaluateTM-Studie
}

P. A. Fasching ${ }^{1}$, T. Fehm ${ }^{2,41}$, S. Kellner ${ }^{1}$, J. de Waal ${ }^{3}$, M. Rezai ${ }^{4}$, B. Baier ${ }^{3}$, G. Baake ${ }^{5}$, H.-C. Kolberg ${ }^{6}$, M. Guggenberger ${ }^{7}$, M. Warm ${ }^{8,9}$, N. Harbeck 8,10 , R. Würstlein ${ }^{8,10}$, J.-U. Deuker ${ }^{11}$, P. Dall ${ }^{12}$, B. Richter ${ }^{13}$, G. Wachsmann ${ }^{14}$, C. Brucker ${ }^{15}$, J. W. Siebers ${ }^{16}$, N. Fersis ${ }^{17}$, T. Kuhn ${ }^{18}$, C. Wolf ${ }^{19}$, H.-W. Vollert ${ }^{20}$, G.-P. Breitbach ${ }^{21}$, W. Janni ${ }^{22}$, R. Landthaler ${ }^{23}$, A. Kohls ${ }^{24}$, D. Rezek ${ }^{25}$, T. Noesslet ${ }^{26}$, G. Fischer ${ }^{27}$, S. Henschen ${ }^{28}$, T. Praetz ${ }^{29}$, V. Heyl ${ }^{30}$, T. Kühnn ${ }^{31}$, T. Krauß ${ }^{32}$, C. Thomssen ${ }^{33}$, S. Kümmel ${ }^{34}$, A. Hohn ${ }^{35}$, H. Tesch ${ }^{36}$, C. Mundhenke ${ }^{37}$, A. Hein ${ }^{1}$, C. Rauh ${ }^{1}$, C. M. Bayer ${ }^{1}$, A. Jacob ${ }^{38}$, K. Schmidt ${ }^{38}$, E. Belleville ${ }^{39}$, P. Hadji ${ }^{40}$, D. Wallwiener ${ }^{41}$, E.-M. Grischke ${ }^{41}$, M. W. Beckmann ${ }^{1}$, S. Y. Brucker ${ }^{41}$

\section{Key words \\ - breast cancer \\ - aromatase inhibitor \\ - compliance \\ $\checkmark$ endocrine therapy \\ Schlüsselwörter \\ - Brustkrebs \\ - Aromataseinhibitor \\ - Compliance \\ - endokrine Therapie}

Deutschsprachige Zusatzinformationen online abrufbar unter: www.thieme-connect.de/ ejournals/toc/gebfra $\begin{array}{ll}\text { received } & 6.11 .2014 \\ \text { revised } & 17.11 .2014 \\ \text { accepted } & 18.11 .2014\end{array}$

Bibliography

DOI http://dx.doi.org/

10.1055/s-0034-1383401

Geburtsh Frauenheilk 2014; 74 :

1137-1143 @ Georg Thieme

Verlag KG Stuttgart · New York ISSN 0016-5751

\section{Correspondence}

Prof. Peter A. Fasching, MD University Hospital Erlangen Department of Gynecology and Obstetrics

Universitätsstraße 21-23

91054 Erlangen

peter.fasching@uk-erlangen.de

\section{Abstract}

$\nabla$

Introduction: The EvaluateTM study (Evaluation of therapy management and patient compliance in postmenopausal hormone receptor-positive breast cancer patients receiving letrozole treatment) is a prospective, non-interventional study for the assessment of therapy management and compliance in the routine care of postmenopausal women with invasive hormone receptor-positive breast cancer receiving letrozole. The parameters for inclusion in the study are presented and discussed here.

Material and Methods: Between January 2008 and December 2009 a total of 5045 patients in 310 study centers were recruited to the EvaluateTM study. Inclusion criteria were hormone receptor-positive breast cancer and adjuvant treatment or metastasis. 373 patients were excluded from the analysis for various reasons.

Results: A total of 4420 patients receiving adjuvant treatment and 252 patients with metastasis receiving palliative treatment were included in the study. For 4181 patients receiving adjuvant treatment, treatment with the aromatase inhibitor letrozole commenced immediately after surgery (upfront). Two hundred patients had initially received tamoxifen and started aromatase inhibitor treatment with letrozole at 1-5 years after diagnosis (switch), und 39 patients only commenced letrozole treatment 5-10 years after diagnosis (extended endocrine therapy). Patient and tumor characteristics were within expected ranges, as were comorbidities and concurrent medication.

Conclusion: The data from the EvaluateTM study will offer a good overview of therapy management in the routine care of postmenopausal women with hormone receptor-positive breast cancer. Planned analyses will look at therapy compliance and patient satisfaction with how in-

\section{Zusammenfassung \\ $\nabla$}

Einleitung: Die EvaluateTM-Studie (Evaluation of therapy management and patient compliance in postmenopausal hormone receptor positive breast cancer patients receiving letrozole treatment) ist eine prospektive, nicht interventionelle Studie, die das Therapiemanagement und die Compliance im Rahmen der Routineversorgung unter einer Therapie mit Letrozol bei postmenopausalen Patientinnen mit einem invasiven, hormonrezeptorpositiven Mammakarzinom als Studienziel hatte. In dieser Publikation werden die Parameter bei Studieneinschluss berichtet.

Material und Methoden: Von Januar 2008 bis Dezember 2009 wurden insges. 5045 Patientinnen in 310 Prüfzentren in die EvaluateTM-Studie eingeschlossen. Zugelassen waren Patientinnen mit einem hormonrezeptorpositiven Mammakarzinom in der adjuvanten und metastasierten Therapiesituation. 373 Patientinnen mussten aus unterschiedlichen Gründen aus den Analysen ausgeschlossen werden.

Ergebnisse: Insgesamt wurden 4420 Patientinnen in der adjuvanten und 252 Patientinnen in der palliativen (metastasierten) Situation in die Studie eingeschlossen. Bei 4181 Patientinnen in der adjuvanten Situation wurde direkt nach operativer Therapie mit einer Aromataseinhibitortherapie mit Letrozol begonnen (upfront). Bei 200 Patientinnen wurde zunächst Tamoxifen gegeben und in den Jahren 2-5 nach Diagnosestellung mit der Aromatasehemmertherapie mit Letrozol begonnen (switch), und bei 39 Patientinnen erst 6-10 Jahren nach Diagnosestellung (extended endocrine therapy). Die Patientinnenund Tumorcharakteristika lagen ebenso wie die Begleiterkrankungen und die Begleitmedikation im Bereich des Erwarteten.

Schlussfolgerung: Die Daten der EvaluateTMStudie werden einen guten Einblick in das Thera- 
formation is conveyed and the contents of the conveyed information. piemanagement von postmenopausalen Patientinnen mit einem hormonrezeptorpositiven Mammakarzinom im Rahmen der Routineversorgung geben. Geplante Analysen beinhalten die Therapiepersistenz und die Zufriedenheit mit den Informationsstrukturen und dem Aufklärungsinhalt.

\section{Introduction}

$\nabla$

Breast cancer treatment has become increasingly individualized in recent years. An enhanced understanding of the molecular basis of breast cancer and the development of biomarkers have contributed to the development of treatment approaches which ensure that, where possible, patients will receive a therapy which will be as effective as possible with the lowest possible side effects [1-4]. Current interest has focused on cancers such as triple-negative breast cancer or HER2 positive breast cancer, not least because of the clear effects of treatment and the recent developments. However, the majority of the 72000 women who develop breast cancer in Germany every year [5] have hormone receptor-positive breast cancer. In recent decades, a lot of progress has been made in developing individualized treatments for these patients, initially with the use of tamoxifen and later with the introduction of aromatase inhibitors. Use of aromatase inhibitors in the adjuvant treatment of postmenopausal patients with hormone receptor-positive breast cancer has greatly changed therapy. While all studies show that recurrence-free survival rates improved compared to treatment with tamoxifen alone, only a few studies have shown that total survival also improved [6-13]. At the time of approval, when benefits were weighed up against the risks of treatment, the benefits were found to clearly outweigh the risks, resulting in the widespread use of aromatase inhibitors to treat hormone receptor-positive breast cancer in postmenopausal women. The reduction in the relative risk of recurrence was reported to be $20 \%$ in the studies which compared 5 years' tamoxifen treatment with 5 years' treatment with aromatase inhibitors (ATAC und BIG 1-98) and was reported to be between 32 and $38 \%$ in the studies which compared 5 years' tamoxifen therapy with a sequence consisting of 2 years' tamoxifen treatment followed by 3 years' aromatase inhibitors (ABCSG8, ARNO, IES-031). Improvements in recurrence-free survival were also noted for extended adjuvant treatment (treatment administered 6-10 years after diagnosis and after 5 years of treatment with tamoxifen) [14-16].

Management of side effects has focused primarily on menopausal symptoms; treatment of these symptoms in clinical practice is important for both patients and doctors, as management may require additional medication or a switch to anti-hormone treatment or therapy may even have to be discontinued. The current standard of care consists of at least 5 years' treatment with adjuvant hormone therapy to achieve similar therapeutic effects as were obtained in clinical trials [17]. But not all patients take the required doses and not all patients continue therapy for 5 years [18-21]; this known problem is referred to as non-adherence to therapy or non-compliance. While adjuvant, anti-hormone treatment of breast cancer is associated with high rates of non-compliance in patients, other approaches such as chemotherapy and radiation as well as follow-up are also associated with relevant rates of non-compliance [22,23].

There are currently no large prospective studies on letrozole. The predictors of non-compliance, which could help identify the groups at risk for this behavior at the start of therapy, are also unknown.

The EvaluateTM study (evaluating letrozole therapy in the management of primary, hormone receptor-positive breast cancer) was carried out to obtain information on patient-driven noncompliance and therapy management.

The goal of the EvaluateTM study was to determine the percentage of postmenopausal patients who were prescribed letrozole therapy for hormone receptor-positive breast cancer as part of their standard care and discontinued therapy within the space of one year. Additional study goals included the identification of predictors which would allow such patients to be detected at an early stage, and the documentation and assessment of the information provided to patients. This paper gives a description of patient and tumor characteristics together with the relevant comorbidities and the variables influencing the decision for treatment.

\section{Methods \\ $\nabla$}

\section{Study design}

The EvaluateTM study is a prospective, single-arm, non-interventional study open to all patients with invasive breast cancer in whom treatment with the aromatase inhibitor letrozole is indicated. This includes patients receiving adjuvant therapy with letrozole as their first-line treatment (upfront), patients receiving letrozole after a course of treatment with tamoxifen (switch), patients receiving letrozole after 5 years' anti-hormone (extended) treatment, and patients receiving letrozole for advanced, metastatic disease.

The study aimed to evaluate the factors influencing the therapy decision of both the physician and the patient in standard care, to evaluate and assess patient management of therapy, to evaluate patient compliance using a patient questionnaire, together with an assessment of compliance by the treating physician, and to evaluate the efficacy and tolerability of treatment with letrozole and the incidence of undesirable events during treatment with letrozole as assessed by the physician.

All ethics commissions of the study centers involved approved the study. The leading ethics commission was the Ethics Commission for the Medical Faculty of the University of Erlangen-Nuremberg. All patients gave their written informed consent to participate in the study.

\section{Documentation}

Participating patients and physicians completed predefined questionnaires at the start of the study, after 6 months and after 12 months ( Fig. 1). On inclusion in the study, physicians documented each patient's prior clinical history, including prior history of breast cancer and prior treatment, concurrent medication and comorbidities. The patient's general state of health was assessed and information about the contents of the information given to patients about aromatase inhibitor therapy, the reasons behind the decision for letrozole therapy and the patient's struc- 


\begin{tabular}{|c|c|c|c|}
\hline & Start of the study & After 6 months & After 12 months \\
\hline \multirow{3}{*}{ 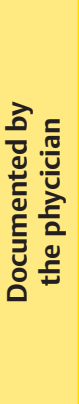 } & $\begin{array}{l}\text { Therapy goals } \\
\text { Comorbidities } \\
\text { Concurrent medication } \\
\text { Patient characteristics } \\
\text { Primary disease } \\
\text { Primary therapy }\end{array}$ & $\begin{array}{l}\text { Progress of disease } \\
\text { Concurrent medication } \\
\text { Undesirable events (ongoing) }\end{array}$ & $\begin{array}{l}\text { Progress of disease } \\
\text { Concurrent medication } \\
\text { Undesirable events (ongoing) }\end{array}$ \\
\hline & $\begin{array}{l}\text { Contents of information provided } \\
\text { to patients }\end{array}$ & Compliance documented by physician & Compliance documented by physician \\
\hline & $\begin{array}{l}\text { Reasons for therapy decision } \\
\text { Infrastructure of patient care }\end{array}$ & $\begin{array}{l}\text { Assessment of efficacy and } \\
\text { tolerability of therapy }\end{array}$ & $\begin{array}{l}\text { Assessment of efficacy and } \\
\text { tolerability of therapy }\end{array}$ \\
\hline \multirow{3}{*}{ 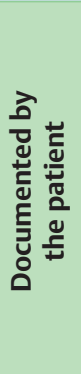 } & Compliance profile of the patient & $\begin{array}{l}\text { Compliance questionnaire } \\
\text { completed by patient }\end{array}$ & $\begin{array}{l}\text { Compliance questionnaire } \\
\text { completed by patient }\end{array}$ \\
\hline & $\begin{array}{l}\text { Assessment of efficacy and } \\
\text { tolerability of therapy }\end{array}$ & $\begin{array}{l}\text { Assessment of efficacy and } \\
\text { tolerability of therapy }\end{array}$ & $\begin{array}{l}\text { Assessment of efficacy and } \\
\text { tolerability of therapy }\end{array}$ \\
\hline & $\begin{array}{l}\text { Contents of information provided } \\
\text { to patients } \\
\text { Reasons for therapy decision } \\
\text { Infrastructure of patient care }\end{array}$ & & \\
\hline
\end{tabular}

ture of care during letrozole therapy were documented. Progress of disease, compliance, the date of discontinuation of treatment (if this occurred) together with the reasons for discontinuing the treatment and the side effects of treatment were documented during the further course of the study. On inclusion in the study, each patient was questioned about the contents of the information on treatment provided to the patient and the patient's satisfaction with this information, as well as the sources of information on aromatase inhibitor therapy. In addition, patients were requested to provide information about their general compliance with treatment. During the study, patients were then asked about their compliance with treatment and how they assessed the efficacy and tolerability of the medication. Documentation was done using questionnaires, and the data obtained was subsequently entered in an electronic documentation system.

\section{Study centers and patient population}

Between January 2008 and December 2009 a total of 5045 patients in 310 study centers across Germany were included in the study. The number of patients per center included in the study ranged from 1 to 213 , with a median of 12 .

Of these 5045 patients, 370 were excluded from the study because information such as date of disease, start of therapy or intention were incomplete. Three more patients were excluded from the study because they had hormone receptor-negative breast cancer. In the end, the study consisted of 4672 patients whose data could be analyzed.

\section{Statistical analysis}

The data presented here describes the patient population and the patient characteristics collected at the start of the study. The study also aimed to investigate the connection between the factors cited by the physician as influencing the decision to pre- scribe letrozole therapy and the different patient groups. Patient groups were defined as follows: Group 1 (adjuvant upfront): patients are prescribed adjuvant therapy with letrozole within 1 year after diagnosis; Group 2 (adjuvant, 2-5 years): patients are prescribed adjuvant therapy with letrozole $1-5$ years after diagnosis; Group 3: patients are prescribed adjuvant therapy with letrozole 6-10 after diagnosis; and Group 4: patients are prescribed letrozole as a palliative treatment (patients with metastatic disease). The information about the factors physicians had considered when making their decision about the prescribed therapy were available as dichotomous variables. Associations between variables were assessed using chi-square test. P-values $<0.05$ were considered statistically significant. Statistical analysis was done using IBM SPSS Statistics Version 21.

\section{Results}

Mean age of patients included in the study was $64.8( \pm 8.5)$ years. Most patients were included in the study because they were prescribed adjuvant therapy ( $n=4420$ of 4672 ). A total of 252 patients had metastatic disease on inclusion in the study. The vast majority of patients receiving adjuvant therapy were in the group receiving letrozole within 1 year after diagnosis $(n=4181,94.6 \%)$, 200 patients began therapy $1-5$ years after diagnosis, and 39 patients began therapy $6-10$ years after diagnosis. The median time from diagnosis to the start of therapy was 0.2 years, 2.3 years, 6.0 years and 0.5 years, respectively ( Table 1 ). As expected, the percentage of patients with ECOG 0 or 1 was lowest in the group with metastatic disease (86.1\%). In the group of patients treated upfront, the percentage of patients with ECOG 0 or 1 was $96.3 \%$. The general state of health of all patients included in the study was therefore very good. 
Table 1 Distribution of patients to the different therapeutic regimens (total patient population, $n=4672$ ).

\begin{tabular}{|c|c|c|c|c|}
\hline Patient group & $\begin{array}{l}\mathbf{n} \text { (\% of total } \\
\text { patient population) }\end{array}$ & $\begin{array}{l}\text { Years between diagnosis and } \\
\text { starting therapy (median) }\end{array}$ & $\begin{array}{l}\text { Age (mean } \pm \\
\text { standard deviation) }\end{array}$ & $\begin{array}{l}\text { ECOG } 0 \text { or } 1 \\
n \text { (\% of this subgroup) }\end{array}$ \\
\hline $\begin{array}{l}\text { Adjuvant, patient started letrozole } \\
\text { within } 1 \text { year after diagnosis }\end{array}$ & 4181 (89.5) & 0.20 & $65.0( \pm 8.4)$ & $4018(96.3)$ \\
\hline $\begin{array}{l}\text { Adjuvant, patient started letrozole } \\
1-5 \text { years after diagnosis }\end{array}$ & $200(4.3)$ & 2.32 & $61.5( \pm 9.3)$ & $198(99.5)$ \\
\hline $\begin{array}{l}\text { Adjuvant, patient started letrozole } \\
6-10 \text { years after diagnosis }\end{array}$ & $39(0.8)$ & 6.03 & $60.2( \pm 10.2)$ & $36(92.3)$ \\
\hline Metastatic disease & $252(5.4)$ & 0.49 & $66.1( \pm 11.1)$ & $217(86.1)$ \\
\hline
\end{tabular}

Table 2 Patient and tumor characteristics of patients receiving adjuvant treatment $(n=4420)$.

\begin{tabular}{|c|c|c|}
\hline Patient characteristics & $\mathrm{n}$ or mean & $\%$ or SD \\
\hline Age & 64.8 & \pm 8.5 \\
\hline BMI & 27.4 & \pm 5.2 \\
\hline \multicolumn{3}{|l|}{ pT } \\
\hline D $0 /$ is* $^{*}$ & 20 & 0.4 \\
\hline$>1$ & 2556 & 58.1 \\
\hline$>2$ & 1517 & 34.5 \\
\hline$>3$ & 185 & 4.2 \\
\hline$>4$ & 123 & 2.8 \\
\hline unknown & 19 & \\
\hline \multicolumn{3}{|l|}{$\mathrm{pN}$} \\
\hline$>0$ & 2801 & 65.5 \\
\hline$>1$ & 969 & 22.6 \\
\hline$\checkmark 2$ & 314 & 7.3 \\
\hline$>3$ & 195 & 4.6 \\
\hline unknown & 141 & \\
\hline \multicolumn{3}{|l|}{ Grade } \\
\hline - 1 & 652 & 14.9 \\
\hline$\checkmark 2$ & 3014 & 68.7 \\
\hline$>3$ & 722 & 16.5 \\
\hline - unknown & 32 & \\
\hline \multicolumn{3}{|l|}{ HER2 } \\
\hline - negative & 3803 & 86.8 \\
\hline positive & 577 & 13.2 \\
\hline unknown & 40 & \\
\hline \multicolumn{3}{|c|}{ (Neo-)adjuvant chemotherapy } \\
\hline no & 2743 & 37.9 \\
\hline yes & 1676 & 62.1 \\
\hline - unknown & 1 & \\
\hline \multicolumn{3}{|c|}{ Adjuvant radiation completed } \\
\hline$>$ no & 2416 & 54.7 \\
\hline yes & 2003 & 45.3 \\
\hline unknown & 1 & \\
\hline \multicolumn{3}{|c|}{ Started trastuzumab therapy } \\
\hline no no & 4270 & 96.6 \\
\hline yes & 149 & 3.4 \\
\hline - unknown & 1 & \\
\hline
\end{tabular}

The patient characteristics of patients receiving adjuvant treatment are shown in $\bigcirc$ Table 2 . Most patients had a stage pT1 tumor $(58.1 \%)$ and were node-negative (65.5\%). Grade 2 tumors were present in $68.7 \%$ of cases and $13.2 \%$ of cases had a positive HER2 status. Data on therapies recorded during the study were within expected ranges ( $\bullet$ Table 2 ).

In this postmenopausal patient population, more than half of all patients had one or more comorbidities. Around $42 \%$ had a vascular disorder (usually hypertension) and approximately $15 \%$
Table 3 Comorbidities (total patient population, $n=4672$ ).

\begin{tabular}{|c|c|c|}
\hline Disease group & $\mathbf{n}$ & $\%$ \\
\hline Vascular disorders* & 1968 & 42.1 \\
\hline Metabolic disorders & 691 & 14.8 \\
\hline Endocrine disorders & 640 & 13.7 \\
\hline Musculoskeletal disorders & 422 & 9.0 \\
\hline Cardiac disorders & 395 & 8.5 \\
\hline Condition after surgery & 300 & 6.4 \\
\hline Other malignant disease & 211 & 4.5 \\
\hline Respiratory and pulmonary disorders & 226 & 4.8 \\
\hline Psychiatric disorders & 216 & 4.6 \\
\hline Neurologic disorders & 216 & 4.6 \\
\hline Gastrointestinal disorders & 140 & 3.0 \\
\hline Eye disorders & 90 & 1.9 \\
\hline Renal and urinary disorders & 71 & 1.5 \\
\hline Infections & 69 & 1.5 \\
\hline Other disorders & 317 & 6.8 \\
\hline
\end{tabular}

had a metabolic disorder (most commonly diabetes type II). The third most common type of comorbidities were endocrine disorders (13.7\%). Particularly important for patients treated with aromatase inhibitors was that $9 \%$ had previous musculoskeletal disorders ( Table 3). The concurrent medication taken by patients corresponded to the profile of patients' comorbidities. 1714 patients $(36.7 \%)$ were taking medication for vascular disease. Out of the total patient population, $23.9 \%$ were taking renin-angiotensin medication, $21.5 \%$ were taking beta-blockers and $6.6 \%$ were taking calcium channel blockers. Around $10 \%$ of patients were taking analgesic drugs, which included oral analgesics, topical analgesics and antiinflammatory and antirheumatic drugs, as shown in $\bigcirc$ Table 4.

The results of the analysis which looked at the factors cited by the physician influencing the decision for aromatase inhibitor therapy are listed in Table 5. As expected, hormone receptor status was the most important factor. The high percentage of physicians (76\%) who invoked the decision taken by the Tumor Board is a reflection of the decision-making structures in breast centers. Looking at the differences between the factors cited as influencing the decision for aromatase inhibitor therapy in the different patient groups, it is clear that the importance of all factors varied across the different patient groups, with the exception of the type of previous surgery and the involvement of the patient in decision-making. These two factors were equally important across all patient groups ( $\bigcirc$ Table 5 ). Tumor stage was cited more often as contributing to decision-making in the upfront therapy group (62.6\%) compared to the other groups (57.5\%/53.8\%/53.6\%, respectively). Age and HER2 status also appeared to be more im- 
Table 4 Concurrent medication at the start of the trial.

\begin{tabular}{lll} 
Medication & \multicolumn{1}{l}{$\mathbf{n}$} & \multicolumn{1}{l}{$\%$} \\
Renin-angiotensin agents & 1115 & 23.9 \\
\hline Beta-blockers & 1004 & 21.5 \\
\hline Thyroid medication & 693 & 14.8 \\
\hline Antithrombotic agents & 418 & 8.9 \\
\hline Lipid modifying agents & 394 & 8.4 \\
\hline Analgesics & 363 & 7.8 \\
\hline Topical analgesics & 362 & 7.7 \\
\hline Diuretics & 355 & 7.6 \\
\hline Oral rinses & 328 & 7.0 \\
\hline Calcium channel blockers & 307 & 6.6 \\
\hline Antidiabetic agents & 284 & 6.1 \\
\hline Antacids & 262 & 5.6 \\
\hline Ophthalmologic drugs & 231 & 4.9 \\
\hline Psychoanaleptics & 213 & 4.6 \\
\hline Mineral supplements & 160 & 3.4 \\
\hline Cardiac medication & 153 & 3.3 \\
\hline Psycholeptics & 133 & 2.8 \\
\hline Antiinflammatory and antirheumatic drugs & 121 & 2.6 \\
\hline Drugs for obstructive airway disease & 114 & 2.4 \\
\hline All other drugs & 786 & 16.8 \\
\hline
\end{tabular}

portant in the decision for upfront therapy, while previous chemotherapies were cited more often as guiding decision-making for the group of patients with metastatic disease.

\section{Discussion}

$\nabla$

Over a period of 2 years more than 5000 patients in more than 300 study centers were included in the EvaluateTM study. Goals of the study were the analysis of the factors influencing the decision for therapy and the identification of predictors for therapy compliance. As expected, the majority of patients were recruited to the study upfront and only a few patients included in study had already undergone extended adjuvant treatment or had metastatic disease. The remaining patient characteristics were within expected ranges. When the factors which physicians had used when making their decision about the preferred type of therapy were compared, the expected differences between patient groups were found.

The EvaluateTM study is one of three prospective studies with a large number of patients which have considered the issue of compliance in aromatase inhibitor therapy.

The PACT study (Patient's Anastrozole Compliance to Therapy) was a prospective randomized study which also included around
5000 patients [24]. In the PACT study, patients were randomized into one of two groups: one group where patients regularly received information about the disease and the anti-hormone treatment during the first year of treatment and one group which did not receive this regular information. The study population receiving adjuvant treatment was very similar to that of the EvaluateTM study [24]. Randomization in the PACT study was analyzed with regard to compliance. Compliance was defined as the percentage of patients who reported after one year that that they had always or almost always taken the drug anastrozole. Compliance in the intervention arm of the study was $88.8 \%$ and was $88.5 \%$ in the standard arm [20]. Multivariate analysis showed that participation in rehabilitation programs, whether the patient was working or not, regular follow-up and the occurrence of undesirable side effects were all factors which influenced compliance [20].

The single-arm COMPACT study (COMPliance and Arthralgia in Clinical Therapy) included approximately 2000 patients who received anastrozole upfront; the COMPACT study investigated the association between the occurrence of joint pain as a side effect and compliance [21]. A significant association was found between the occurrence of arthralgias and compliance. The rate of non-compliance ranged from around $10 \%$ to almost $30 \%$, as a function of the arthralgia score (range 0-100) [21]. Interestingly, this study showed a significant difference between compliance as reported by physicians and compliance as reported by patients. While physicians assessed compliance after 9 months as more than $95 \%$, patients reported a compliance rate of less than $70 \%$.

Another study which analyzed prescription databases reported that the rate of patients who had not taken any anastrozole or had not taken sufficient anastrozole at 12 months was between 82 and $88 \%$. Approximately 12000 patients were included in this study [18].

Similar to the PACT and the COMPACT studies, the EvaluateTM study will be investigating predictors for compliance.

In contrast to the studies described above, the EvaluateTM study was also able to include patients with advanced disease and patients who started treatment with the aromatase inhibitor letrozole at a later date. The number of patients who began treatment 5-10 years after diagnosis appears relatively low. Treatment with letrozole after 5 years' prior treatment with tamoxifen has been reported to result in improved disease-free survival rates [16]. A benefit with regard to total survival has even been discussed for certain subgroups such as node-positive patients [25,26]. In the EvaluateTM study $35.5 \%$ of patients were node-positive. If we assume that this corresponds to the percentage of patients who were offered extended adjuvant therapy, then the number of 39

Table 5 Association between the factors cited by the physician as influencing the choice of therapy and the patient group (total patient population, $\mathrm{n}=4672$ ).

\begin{tabular}{|c|c|c|c|c|c|c|}
\hline Factor & All (\%) & $\begin{array}{l}\text { Adjuvant } \\
\text { upfront (\%) }\end{array}$ & $\begin{array}{l}\text { Adjuvant, } \\
1-5 \text { years (\%) }\end{array}$ & $\begin{array}{l}\text { Adjuvant, } \\
\text { 5-10 years (\%) }\end{array}$ & $\begin{array}{l}\text { Metastatic } \\
\text { disease (\%) }\end{array}$ & p-value \\
\hline TNM stage & $2887(61.8)$ & $2616(62.6)$ & $115(57.5)$ & $21(53.8)$ & $135(53.6)$ & 0.012 \\
\hline Hormone receptor status & $3738(80.0)$ & $3386(81.0)$ & $140(70.0)$ & $29(74.4)$ & $183(72.6)$ & $<0.001$ \\
\hline HER2 status & 917 (19.6) & $865(20.7)$ & $20(10.0)$ & $3(7.7)$ & $29(11.5)$ & $<0.001$ \\
\hline Type of surgery & $489(10.5)$ & $442(10.6)$ & $17(8.5)$ & $4(10.3)$ & $26(10.3)$ & 0.830 \\
\hline Previous chemotherapies & $361(7.7)$ & $319(7.6)$ & $7(3.5)$ & $1(2.6)$ & $34(13.5)$ & $<0.001$ \\
\hline Age & $2269(48.6)$ & $2088(49.9)$ & $63(31.5)$ & $16(41.0)$ & $102(40.5)$ & $<0.001$ \\
\hline Patient's decision & $1012(21.7)$ & $915(21.9)$ & $35(17.5)$ & $8(20.5)$ & $54(21.4)$ & 0.531 \\
\hline Tumor Board & $3551(76.0)$ & $3249(77.7)$ & $126(63.0)$ & $20(51.3)$ & $156(61.9)$ & $<0.001$ \\
\hline
\end{tabular}


patients reported in der EvaluateTM study is very low. Other reasons, such as bias during study recruitment or the increasing use of aromatase inhibitors in the first 5 years after diagnosis of disease, probably played a role for this low figure. But the suspicion that patients who could benefit from such a therapy did not receive this option remains.

When looking at the factors cited by physicians as influencing their therapy decision, it became clear that for patients prescribed aromatase inhibitor therapy upfront, tumor stage, patient age and HER2 status were referred to significantly more often as important factors for the therapy decision. Even if it was not possible to inquire into the causes for this association, it could be supposed that patients who have a higher tumor stage and a positive HER2 status and who are postmenopausal but younger, were prescribed aromatase inhibitor more often to guard against a higher risk of recurrence. It also appears plausible that when decisions are taken immediately after diagnosis, the decision of the Tumor Board plays a greater role than for patients who receive letrozole at a later point in time. Even if the percentage of patients involved in the therapy decision appears to be rather low at around $20 \%$, the involvement of the patient in the therapy decision does not occur independently of the stage of disease; despite the low rate of involvement, it reflects the importance and independence of this factor.

Overall, the EvaluateTM study provides a good overview of therapy management, compliance and side effects of therapy with letrozole. All patients were homogeneously treated with the aromatase inhibitor letrozole, and patients and physicians were questioned prospectively with regard to the goals of the study (هig. 1). The study aims to depict therapy management and compliance in clinical practice.

Planned analyses include the identification of predictors of therapy compliance and the analysis of quality parameters for therapy management as well as an analysis of patients' information needs and patient satisfaction with the available care infrastructure and the information provided.

\section{Acknowledgements \\ $\nabla$}

We would like to thank the patients and staff involved in the study. We would also like to thank Novartis for its financial support which enabled us to carry out the study and for the funding towards the costs of publication. Furthermore we would like to express our thanks to the participating study centers and to all patients who participated in the study. All analyses were done independent of Novartis. This manuscript was also prepared independently from Novartis. Data sovereignty remains with the principal medical investigators.

\section{Conflict of Interest}

$\nabla$

P.A.F. received fees from the following companies: Amgen, Roche, Novartis, Pfizer, Genomic Health and received research funding from Novartis and Amgen. H.-C.K. received fees from Novartis, Amgen, GlaxoSmithKline, Teva, Carl Zeiss Meditech, Theraclion. M.G. received fees from AstraZeneca, Roche, Novartis. S.K. received fees from Novartis, Roche, Celgene, TEVA, Amgen. H.T. received fees from Novartis. N.H. received fees from Novartis. N.F. received fees and research funding from Novartis. C.T. received fees from Novartis, Pfizer and AstraZeneca. R.W. received fees and research funding from Novartis. E.B. received fees from Novartis. K.S. and A.J. are employees of Novartis Pharma.

\section{Affiliations}

1 Universitäts-Brustzentrum Franken, Frauenklinik, Universitätsklinikum Erlangen, Friedrich-Alexander Universität Erlangen-Nürnberg, Comprehensive Cancer Center Erlangen-EMN, Erlangen

${ }^{2}$ Universitäts-Frauenklinik Düsseldorf, Düsseldorf

${ }^{3}$ Frauenklinik im Klinikum Dachau, Dachau

${ }^{4}$ Luisenkrankenhaus Düsseldorf, Düsseldorf

${ }^{5}$ Klinikum Pinneberg, Pinneberg

${ }^{6}$ Marienhospital Bottrop, Bottrop

${ }^{7}$ Klinikum Tuttlingen, Tuttlingen

8 Brustzentrum, Universitäts-Frauenklinik Köln, Köln

${ }^{9}$ Brustzentrum, Klinken der Stadt Köln gGmbH Holweide, Köln

${ }^{10}$ Brustzentrum der Universität München, Frauenkliniken Großhadern und Maistrasse-Innenstadt, München

11 Vinzenzkrankenhaus Hannover gGmbH, Hannover

${ }^{12}$ Frauenklinik, Klinikum Lüneburg, Lüneburg

${ }^{13}$ Elblandkliniken Meißen-Radebeul Standort Radebeul, Radebeul

${ }^{14}$ Kreiskrankenhaus Böblingen, Böblingen

15 Universitätsklinik für Frauenheilkunde, Paracelsus Medizinische Privatuniversität, Nürnberg

${ }^{16}$ Frauenklinik des St. Josefsklinik Offenburg, Offenburg

17 Frauenklinik, Klinikum Bayreuth GmbH, Comprehensive Cancer Center Erlangen-EMN, Bayreuth

${ }^{18}$ Karl-Olga-Krankenhaus, Stuttgart

${ }^{19}$ Medizinisches Zentrum Ulm, Ulm

20 Klinikum Friedrichshafen, Friedrichshafen

${ }^{21}$ Städtisches Klinikum Neunkirchen Gynäkologie und Geburtshilfe, Neunkirchen

22 Frauenklinik des Universitätsklinikums Ulm, Ulm

${ }_{23}$ Gynäkologische Praxis in der Kreisklinik, Krumbach

24 Evangelisches Krankenhaus Ludwigsfelde-Teltow, Ludwigsfelde

${ }^{25}$ Marien-Hospital Wesel, Wesel

${ }^{26}$ Frauenklinik am Kreiskrankenhaus Hameln, Hameln

27 Landkreis Mittweida Krankenhaus gGmbH, Mittweida

28 Johanniter Krankenhaus Genthin Stendal gGmbH, Stendal

29 Praxis Dr. Praetz, Bad Mergentheim

${ }^{30}$ Asklepios Paulinen Klinik Wiesbaden, Wiesbaden

31 Frauenklinik, Städtische Kliniken Esslingen a. N., Esslingen

32 Frauenklinik Lippe, Lippe

${ }^{33}$ Frauenklinik, Universitätsklinik Halle Wittenberg, Halle

${ }^{34}$ Brustzentrum, Kliniken Essen Mitte, Evang. Huyssens-Stiftung/Knappschaft $\mathrm{GmbH}$, Essen

${ }^{35}$ Kreiskrankenhaus Rendsburg, Rendsburg

36 Onkologie Bethanien, Frankfurt

37 Universitätsklinikum Schleswig-Holstein Campus Kiel, Kiel

38 Novartis Pharma GmbH, Nürnberg

${ }^{39}$ Clin-Sol GmbH, Würzburg

${ }^{40}$ Krankenhaus Nordwest, Klinik für Gynäkologie und Gebursthilfe, Frankfurt

${ }^{41}$ Universitätsfrauenklinik Tübingen, Tübingen

\section{References}

1 Lux MP, Maass N, Schutz F et al. Breast cancer 2013 - interpretation of new and known data. Geburtsh Frauenheilk 2013; 73: 584-598

2 Schutz F, Domschke C, Hennigs A et al. Immunotherapy in breast cancer. Geburtsh Frauenheilk 2012; 72: 989-990

3 Sinn P, Aulmann S, Wirtz R et al. Multigene assays for classification, prognosis, and prediction in breast cancer: a critical review on the background and clinical utility. Geburtsh Frauenheilk 2013; 73: 932940

4 Fersis N, Friedrich M. Reflections after the 35th San Antonio Breast Cancer Symposium. Geburtsh Frauenheilk 2013; 73: 262-265

5 Eisemann N, Waldmann A, Katalinic A. Epidemiology of breast cancer current figures and trends. Geburtsh Frauenheilk 2013; 73: 130-135

6 Coombes RC, Hall E, Gibson $L J$ et al. A randomized trial of exemestane after two to three years of tamoxifen therapy in postmenopausal women with primary breast cancer. N Engl J Med 2004; 350: 10811092

7 Kaufmann M, Jonat W, Hilfrich J et al. Improved overall survival in postmenopausal women with early breast cancer after anastrozole initiated after treatment with tamoxifen compared with continued tamoxifen: the ARNO 95 Study. J Clin Oncol 2007; 25: 2664-2670 
8 Jakesz R, Jonat W, Gnant $M$ et al. Switching of postmenopausal women with endocrine-responsive early breast cancer to anastrozole after 2 years' adjuvant tamoxifen: combined results of ABCSG trial 8 and ARNO 95 trial. Lancet 2005; 366: 455-462

9 Regan MM, Neven P, Giobbie-Hurder A et al. Assessment of letrozole and tamoxifen alone and in sequence for postmenopausal women with steroid hormone receptor-positive breast cancer: the BIG 1-98 randomised clinical trial at 8.1 years median follow-up. Lancet Oncol 2011; 12: $1101-1108$

10 Thurlimann B, Keshaviah A, Coates AS et al. A comparison of letrozole and tamoxifen in postmenopausal women with early breast cancer. N Engl J Med 2005; 353: 2747-2757

11 Howell A, Cuzick J, Baum M et al. Results of the ATAC (Arimidex, Tamoxifen, Alone or in Combination) trial after completion of 5 years' adjuvant treatment for breast cancer. Lancet 2005; 365: 60-62

12 Baum M, Budzar AU, CuzickJ et al. Anastrozole alone or in combination with tamoxifen versus tamoxifen alone for adjuvant treatment of postmenopausal women with early breast cancer: first results of the ATAC randomised trial. Lancet 2002; 359: 2131-2139

13 Pagani O, Regan MM, Walley BA et al. Adjuvant exemestane with ovarian suppression in premenopausal breast cancer. N Engl J Med 2014; 371: $107-118$

14 Jakesz R, Greil R, Gnant $M$ et al. Extended adjuvant therapy with anastrozole among postmenopausal breast cancer patients: results from the randomized Austrian Breast and Colorectal Cancer Study Group Trial 6a. J Natl Cancer Inst 2007; 99: 1845-1853

15 Mamounas EP, Jeong JH, Wickerham DL et al. Benefit from exemestane as extended adjuvant therapy after 5 years of adjuvant tamoxifen: intention-to-treat analysis of the National Surgical Adjuvant Breast And Bowel Project B-33 trial. J Clin Oncol 2008; 26: 1965-1971

16 Goss PE, Ingle JN, Martino $S$ et al. A randomized trial of letrozole in postmenopausal women after five years of tamoxifen therapy for earlystage breast cancer. N Engl J Med 2003; 349: 1793-1802

17 Ward JH. Duration of adjuvant endocrine therapy of breast cancer: how much is enough? Curr Opin Obstet Gynecol 2010; 22: 51-55
18 Partridge AH, LaFountain A, Mayer E et al. Adherence to initial adjuvant anastrozole therapy among women with early-stage breast cancer. J Clin Oncol 2008; 26: 556-562

19 Ziller V, Kalder M, Albert US et al. Adherence to adjuvant endocrine therapy in postmenopausal women with breast cancer. Ann Oncol 2009; 20: 431-436

20 Hadji P, Blettner M, Harbeck $N$ et al. The Patient's Anastrozole Compliance to Therapy (PACT) Program: a randomized, in-practice study on the impact of a standardized information program on persistence and compliance to adjuvant endocrine therapy in postmenopausal women with early breast cancer. Ann Oncol 2013; 24: 1505-1512

21 Hadji P, Jackisch C, Bolten Wet al. COMPliance and Arthralgia in Clinical Therapy: the COMPACT trial, assessing the incidence of arthralgia, and compliance within the first year of adjuvant anastrozole therapy. Ann Oncol 2014; 25: 372-377

$22 \mathrm{Ma}$ AM, Barone J, Wallis AE et al. Noncompliance with adjuvant radiation, chemotherapy, or hormonal therapy in breast cancer patients. Am J Surg 2008; 196: 500-504

23 Geller BM, Kerlikowske K, Carney PA et al. Mammography surveillance following breast cancer. Breast Cancer Res Treat 2003; 81: 107-115

24 Harbeck N, Blettner M, Hadji P et al. Patient's Anastrozole Compliance to Therapy (PACT) Program: baseline data and patient characteristics from a population-based, randomized study evaluating compliance to aromatase inhibitor therapy in postmenopausal women with hormone-sensitive early breast cancer. Breast Care (Basel) 2013; 8: 110 120

25 Goss PE, Ingle JN, Martino S et al. Randomized trial of letrozole following tamoxifen as extended adjuvant therapy in receptor-positive breast cancer: updated findings from NCIC CTG MA.17. J Natl Cancer Inst 2005; 97: 1262-1271

26 Goss PE, Muss HB, Ingle JN et al. Extended adjuvant endocrine therapy in breast cancer: current status and future directions. Clin Breast Cancer 2008; 8: 411-417 